\title{
Application the Statistical Methods for Estimating of Innovation Level
}

\author{
Turcan Aurelia \\ Associate Professor, PHD \\ Vice-Rector, University of European Studies of Moldova \\ E-mail: aurasofia@mail.ru \\ Bujor Tatiana \\ Associate Professor, PHD \\ E-mail: bujortania@yahoo.com \\ Bahneanu Vitalina \\ Associate Professor, PHD \\ Dean University of European Studies of Moldova \\ E-mail: francofonie.bahneanu@mail.md
}

Doi:10.5901/mjss.2013.v4n9p271

\section{Abstract}

The innovation process is a complex phenomenon. The complexity of the innovation process consists from the strong link of this process with the researching-development activity and the technological transfer. In this paper some approach to statistical evaluation and estimation of the innovation indicators is presented. After the authors ' opinion the special attention needs to be given to criteria innovation assessing of the socio-economic development. This problem is important both in the world and in Moldova. Identifying sources of innovation and creating models of innovative activity are elements necessary for socioeconomic development scenarios concluding. The researches based on the methods of data analysis and modeling, including the correlation and regressive analysis, assumes the use of methods of the description and measurement of statistical relationship. First of all, this method allows to establish on the average how the productive sign changes under the influence of one or several factors, and secondly - quantitatively to estimate narrowness of relationship between variables. In this work are given examples of the analysis of interrelation of a share of innovative production in total amount of sales of production and the analysis of gain level of profitability of the enterprise.

Keywords: innovation process, level of the innovation, regression, correlation, correlation and regressive analysis, profitability of the enterprise.

\section{Introduction}

Existence of a coherent statistical information system in the field of innovation in Moldova is an urgent task of society, because only in this case it is possible to predict the quality of economic growth.

In this paper some approach of the statistical evaluation and estimation to the innovation activity.

\section{Research methodology}

The supply side is modelled by Cobb-Douglas production function. In the base of this function Total Factor Productivity indicator, which not depend on factors of production, but on the other socio-economic indicators, is calculated.

\section{Findings and discussion}

\subsection{Utilizrea metodei corelativ - regresionale}

The researches based on regression and correlation assumes the use of methods of the description and measurement of 
statistical relationship.

The concept (definition) of regression and correlation are taken from a biometry and has been offered by Fr. Galton. Originally correlation researches occurred in biology, and later have extended on social and economic area. Simultaneously with correlation the regression has started to be used. Correlation and regression are closely connected among themselves and serve for a parity establishment between the phenomena for definition of presence or absence of relationship.

First of all, this method allows to establish on the average how the productive sign changes under the influence of one or several factors, and secondly - quantitatively to estimate narrowness of relationship between variables, i.e. to calculate percent of influence of the concrete factor on the general change of a productive sign.

The correlation method assumes an estimation of intensity relationship's force between two or more variables and revelation of concentration's degree of the fact sheet around regressive lines. The narrowness of relationship is quantitatively expressed by size of correlation's facts which is also an estimation of the equation's conformity of regression to the revealed connection of cause and effect.

The regressive analysis consists in definition of analytical expression of relationship in which the change of one size (productive) is caused by influence of one or several independent sizes, and set of all other factors which without any changing influence on dependent size, is accepted to constants and average values. Studying of regression or regressive modeling assumes use of the whole arsenal of methods to find the most comprehensible model of the form's description of relationship between variables.

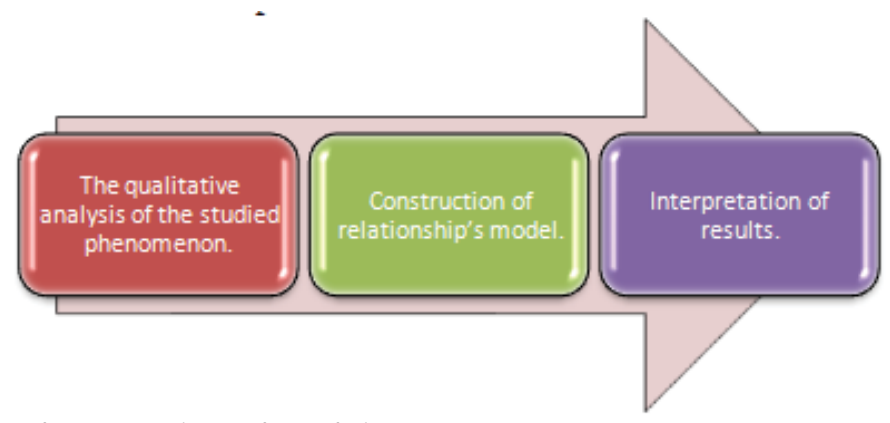

Figure 1. The study based on regression and correlation

Statistical model of relationship of the social and economic phenomena, which is expressed by function of $\mathrm{yx}_{\mathrm{x}} \mathrm{f}\left(\mathrm{x}_{1}, \mathrm{x}_{2}\right.$, $\ldots, \mathrm{xi})$, is called the regression equation, or the equation of correlation relationship.

Regression can be one-factorial (pair) and multi-factorial (multiple), but thus it is necessary to consider that according to an optimum parity between number of a factorial sign and object of investigated set it is necessary to regard as parity 5-6 to 1. Under the dependence form it is distinguished linear and nonlinear regression.

The most used models of regression for relationship's studying between the social and economic phenomena and processes are:

1. The linear regression expressed by the equation of a straight line.

2. The nonlinear regression expressed by a number of mathematical functions: the parabolic; the sedate; the exponential; the hyperbolic; the indicative; logarithmic, etc.

Solution of relationship's mathematical equations assumes calculation under the initial data of their parameters in the way of alignment of the empirical data by the method of the least squares given by a method answering to the requirement of "a method of the least squares":

$$
\sum\left(y_{i}-y_{x i}\right)^{2}=\mathrm{m} \text { in }
$$

At machining of the initial information on the computers equipped with packages of standard programs of conducting the correlation and regressive analysis, calculation of parameters of applied mathematical functions is considered as a counting operation.

Linear pair regression is expressed by the straight line equation:

$\mathrm{yx}=\mathrm{a}_{0}+\mathrm{a}_{1} \mathrm{x}$

where $\mathrm{a}_{0}, \mathrm{a}_{1}$ - parameters of the equation of regression; at which: $\mathrm{a}_{0}$ - the free member of regression accepts value $Y$ when $x=0$, and shows average influence on a productive sign of not considered factors; $a_{1}-$ the factor of 
regression which shows how many units on the average will change a productive sign at change of a factorial sign on unit. The sign at regression factor shows a relationship direction: $\mathrm{a}_{1}>0$ - relationship a straight line (positive) $\mathrm{a}_{1}<0-$ relationship return (negative), $\mathrm{a}_{1}=0$ - absence of relationship.

Multiple regression is considered as a research of statistical dependence of a productive sign $Y$ from several factorial variables $x_{1}, x_{2}, x_{3}, \ldots x_{i}$. At the research of dependences by methods of plural regression the problem is formulated the same as in the use of pair regression, it is required to find function

$y_{1,2, \ldots i}=f\left(x_{1}, x_{2}, \ldots ., x_{i}\right)$.

The drawing up of models of plural regression includes the following stages:

- A choice of the relationship equation;

- Selection of factorial variables;

- Definition of number of the supervision necessary for reception of not displaced estimations.

The fundamental basis of function choice for the equation of multiple regressions is the same, as for measurement of relationship with one sign. Practice of construction of multi-factorial models of interrelation shows that all real-life dependences between the social and economic phenomena can be described by following mathematical functions:

- Linear $y_{1,2, \ldots i}=a_{0}+a_{1} x_{1}+a_{2} x_{2}+\ldots+a_{i} x_{i}$;

- Hyperbolic $y_{1,2, \ldots i}=a_{0}+a_{1} / x_{1}+a_{2} / x_{2}+\ldots+a_{i} / x_{i}$,

- Parabolic $y_{1,2, \ldots i}=a_{0}+a_{1} x_{1}{ }^{2}+a_{2} x_{2}{ }^{2}+\ldots+a_{i} x_{i} i^{2}$;

Indicative $y_{1,2, \ldots i}=e^{a 0+a 1 \times 1+a 2 \times 2+\ldots+a i x i}$;

- $\quad$ exponential $y_{1,2, \ldots i}=a_{0} x_{1}{ }^{a 1} \cdot x_{2}^{a 2} \ldots x_{1}^{a i}$.

One of often used regression's models for economic growth modeling is a Cobb-Douglas function:

$y_{x 1, x 2}=a_{0} x_{1}{ }^{a 1} \cdot x_{2}{ }^{a 2}$,

which expresses the interrelation between national income (final product) and the basic production assets $\mathbf{x}_{1}$ and labor $\mathbf{x}$.

It should be noted that at plotting of regression models appears a problem of multicollinearity which essentially deforms research results. Multicollinearity is considered a close dependence between the factorial variables included in model. One of the indicators defining the presence of multicollinearity between factorial variables is excess of size of pair correlation factor $0,8\left(r_{x i x}>0,8\right)$. The elimination of the multicollinearity can be realized by excluding one or several linearly-connected factorial variables from the correlation model or transforming the initial factorial variables to new integrated factors.

Further we will analyze the dependence of two independent variables (expenditure on R\&D per employee and labor productivity) and result variable (volume of production). For this we stop at multiple linear regressions.

The analytical form of the relationship expression of a productive sign and some factors is called multi-factorial equation of regression or relationship model. The equation of linear multiple regression at $i$ variables looks like $\boldsymbol{y}_{1,2, \ldots i}=$ $a_{0}+a_{1} X_{1}+a_{2} X_{2}+\ldots+a_{i} X i$, where $y_{1,2, \ldots i}-$ the theoretical values of a productive sign received as a result of substitution of corresponding values of factorial variables in the regression equation; $x_{1}, x_{2}, \ldots, x_{i}-$ factorial variables; $a_{1}, a_{2}, \ldots, a_{i}-$ model parameters (regression factors).

Equation parameters can be found in the various ways: the method of least squares, the dot method, the graphic method, the method of splitting the set of investigated objects in groups by the number of found parameters and representing then the dependences between average group indicators as functional one etc. The most wide-spread distribution in finding the regression parameters is the method of the least squares.

Table 2. The Calculation table for determination of the equation's parameters of regression.

\begin{tabular}{|c|c|c|c|c|c|c|c|c|}
\hline $\mathrm{Nr}$ & $\begin{array}{c}\mathrm{X}_{1,} \\
\text { USD } \\
\text { /employee }\end{array}$ & $\begin{array}{c}\mathrm{X}_{2,} \\
\text { Thousand piece } \\
\text { per employee }\end{array}$ & $\begin{array}{c}\mathrm{Y}, \\
\text { Thousand } \\
\text { piece }\end{array}$ & $\mathrm{X}_{1} \mathrm{y}$ & $\mathrm{X}_{2} \mathrm{y}$ & $\mathrm{X}_{2}{ }^{2}$ & $\mathrm{X}_{1}{ }^{2}$ & $\mathrm{X}_{1} \mathrm{X}_{2}$ \\
\hline 1. & 21 & 225 & 14,5 & 304,5 & 3262,5 & 50625 & 441 & 4725 \\
\hline 2. & 13 & 170 & 5,1 & 66,3 & 867 & 28900 & 169 & 2210 \\
\hline 3. & 14 & 150 & 6,5 & 91 & 975 & 22500 & 196 & 2100 \\
\hline 4. & 16 & 150 & 9,1 & 145,6 & 1365 & 22500 & 256 & 2400 \\
\hline 5. & 10 & 130 & 6,5 & 65 & 845 & 16900 & 100 & 1300 \\
\hline 6. & 25 & 825 & 31,1 & 777,5 & 25657,5 & 680625 & 625 & 20625 \\
\hline 7. & 23 & 170 & 5,1 & 117,3 & 867 & 28900 & 529 & 3910 \\
\hline 8. & 15 & 702 & 22,1 & 331,5 & 15514,2 & 492804 & 225 & 10530 \\
\hline
\end{tabular}




\begin{tabular}{|l|c|c|c|c|c|c|c|c|}
\hline 9. & 14 & 150 & 16 & 224 & 2400 & 22500 & 196 & 2100 \\
\hline 10. & 15 & 130 & 6,5 & 97,5 & 845 & 16900 & 225 & 1950 \\
\hline 11. & 23 & 625 & 26,1 & 600,3 & 16312,5 & 390625 & 529 & 14375 \\
\hline total & 189 & 3427 & 148,6 & 2820,5 & 68910,7 & 1773779 & 3491 & 66225 \\
\hline
\end{tabular}

By data about production $-\mathbf{Y}$, level of expenses of $R \& D$ on the employee $-\mathbf{X}_{1}$ and labor productivity $-\mathbf{X}_{2}$ it is possible to define dependence between variables.

Regression statistics

$\begin{array}{ll}\text { Multiple R } & 0,99673 \\ \text { R- square } & 0,993471 \\ \text { Normalized R-square } & 0,991839 \\ \text { Standard error } & 0,88382 \\ \text { Observations } & 11\end{array}$

$\begin{array}{ccccccc} & \text { Coefficients } & \text { Standard } & \text { t-statistic } & \text { P- } & \text { Lower } & \text { Top } \\ & & \text { error } & \text { Significance } & 95 \% & 95 \% \\ \text { Y-intersection } & 0,246059 & 0,423698 & 0,58074104 & 0,57740397 & -0,730989834 & 1,223107005 \\ \text { Variable-X }-X_{1} & 98,85434 & 12,10922 & 8,163559781 & 3,7737 \mathrm{E}-05 & 70,93042761 & 126,7782485 \\ \text { Variable- X2 } & 0,011465 & 0,003147 & 3,643106684 & 0,00655942 & 0,004207864 & 0,01872186\end{array}$

Thus, $y_{i}=0,246+98,85 x_{1}+0,011 x_{2}$.

The factors of the linear equation of plural regression show for how many units changes the function with the argument change of with the fixed position of other arguments at certain level (usually average).

\subsection{Utilization Cobb-Douglas production function}

Based on the methodology of the International Assessment of innovation can apply the methods of statistical and mathematical modelling.

IUS 2010 methodology broadly follows the methodology of previous editions, namely: there are three types of innovation indicators and eight dimensions, which in total represent 25 different indicators.

Possibilities found the main engine of innovation performance of firms and distributed within the dimensions of innovation: Human Resources indicators -3; System Research - 3 indicators; Financial Support - 2 indicators.

Firms Activity are innovative efforts at the firms level and are diversified in three dimensions: Investment Company - 2 indicators, links \& Entrepreneurship includes three indicators, Intellectual Assets.

Outputs contain effects from innovation activities of the firms and are varied on two innovation dimensions:

Innovators - 3 indicators,

Economic Effects - 5 indicators.

This methodology is predestined to balanced evaluation of innovative activity taking into account the diversity of innovation processes taking place in world economies.

Such methodological approaches that were utilised as criteria of real economic activity economic indicators were used by several authors. For example the number of domestic bidders for patent in Russian Federation (Ivanova, I. Dejina, I, 2008) , the share of high technology exports with high scientific rate and the share of high technology exports in total exports were used as performance indicators.

In the publications of the Ukrainian scientists (Sadcov V., 2002, Liubici F., Harazasvili I., Denisiuc V., 2009, Crotov S. 2004,), based on official statistical data, calculations of the indicators that characterize innovation process were performed. In the publications (Crotov S. 2004) have been proposed innovative modalities to assess the level of society development and the integral criteria for innovation economy evaluating. In the publications (Liubici F etc. 2009 ) is proposed an aggregate indicator for assessing of the socio-economic innovation level.

This indicator depends on many factors, such as integrated productivity, technological level of production, the shadow economy, the social equity, and the utilization of labour and also the use of not explored potential. Here the supply is modelled using Cobb-Douglas production function, generalized technological factor being characterized by the innovation level. The components of this integrated criterion for socio-economic effectiveness assessing concerns:

1. GDP per one unit of the production capacity or total productivity;

2. Social equity; 
3. Shadow economy;

4. Labor force utilization;

5. Technology of the production;

6. Potential GDP.

All indicators are normed, the maximum value being equal to one unit, and their product evaluates integrated effectiveness: $E F_{t}=\prod_{1}^{6} k_{i}$. As a criterion for effectiveness degree determining is proposed $I E_{t}=\left(\frac{E F_{t}}{E F_{t-1}}-1\right) 100 \%$. Further, efficiency indicators are calculated based on integrated supply expressed by Cobb-Douglas type production function $Y_{t}=\sigma_{t} \exp (\mathcal{H}) L_{t}^{\alpha t}\left(\vartheta_{t} K_{t}\right)^{(1-\alpha) t}$.

Here $\sigma_{t}$ is the share of GDP in production volume, $\gamma$ is the rate of technical progress, $L_{t}$ are labour costs ( $N=\xi N W), \xi$ determining share of private sector employees in total employment, $N$ are all employees. $K_{t}$ is the production capital cost, $W$ is the nominal annual wage, $\vartheta$ is the coefficient of production capital use.

At the initial stage is assumed that the pace of technical progress is equal to $=0.5 \%$ annually. The authors forward the hypothesis, which argues that the first iteration of this coefficient reflects the innovation. Which enables calculation of the rate of technological progress as endogenous.

Further, this result will be applied to the Republic of Moldova and the calculation of aggregate demand coefficients will use the approach proposed in the publications (Sadcov V., 2002), the production function is Cobb-Douglas type $Y_{t}=\theta_{0} e^{\vartheta_{3} t} K^{\theta_{1}} L^{\theta_{2}}$.

Here $K$ and $L$ is the aggregate stock of capital and labour, $\theta_{i}(i=0,1,2)$ are coefficients to be determined. It is well known that estimating aggregate supply as proposed is a very serious problem because only a few countries in development have dynamic data on capital stocks, so it will apply the method proposed in the publications (Gorbanyov, M., 2010), namely, differential equation $K_{t}=(1-\rho) K_{t-1}+\operatorname{In} v_{t}$ solution in which $\rho$ is the rate of capital depreciation, maz be written as:

$$
\begin{aligned}
& \log K_{t}=\log \left[\sum_{i=0}^{t-1}(1-\rho)^{i} \operatorname{In} v_{t-i}+(1-\rho)^{t} K_{0}\right] \approx \\
& \log 2+\frac{1}{2}\left[\log \sum_{i=0}^{t-1}(1-\rho)^{i} \operatorname{In} v_{t-1}+\log (1-\rho)^{t} K_{0}\right]= \\
& =\log 2+\frac{1}{2} \log \sum_{i=0}^{t-1}(1-\rho)^{i} I_{t-1}+\frac{t}{2} \log (1-\rho)+\frac{1}{2} \log K_{0}
\end{aligned}
$$

Here $K_{0}$ is the initial capital stock. So, $\log Y_{t}=\log \theta_{0}+\theta_{1} \log K_{t}+\theta_{2} \log L_{t}=\theta_{0}^{\prime}+\theta_{1} K_{t}^{\prime}+\theta_{2} \log L_{t}$

$$
\theta_{0}^{\prime}=\log \theta_{0}+\frac{\theta_{1}}{2} \log K_{0} \quad K_{t}^{\prime}=\log 2+\frac{1}{2} \log \sum_{i=0}^{t-1}(1-\rho)^{i} \operatorname{In} v_{t-1}+\frac{t}{2} \log (1-\rho)
$$

(Here is used the following decomposition in series

$$
\begin{aligned}
& \log (x+y) \approx \log 2+\frac{1}{2}(\log x+\log y)+\frac{1}{8}(\log x-\log y)^{2}+\ldots, \\
& \text { here } x=\sum_{i=0}^{t-1}(1-\rho)^{i} I_{t-i}, y=(1-\rho)^{t} K_{0} \text {. As in [13] } K_{0}=2.5^{*} Y .
\end{aligned}
$$

Suppose constant return to scale, then $\left(\theta_{1}+\theta_{2}=1\right)$, and dividing expression for the aggregate supply in the 
logarithm to the $\log \left(L_{t}\right)$ obtaining: $\log \left(Y_{t} / L_{t}\right)=\theta_{0}^{\prime}+\theta_{1}\left(K_{t}^{\prime}-\log L_{t}\right)$. Then insert a term into the equation dependent on $t$, that it becomes $\log \left(Y_{t} / L_{t}\right)=\theta_{0}^{\prime}+\theta_{1}\left(K_{t}^{\prime}-\log L_{t}\right)+g t$.

The present model has been estimated under complete price-wage flexibility. In these circumstances, the previous equation is the aggregate supply function: the value of TFP is estimated at about $5.9 \%$ and the production function coefficients of 0.73 and 0.27 respectively, are higher than those estimated in this parers ( Gorbanyov, M. 2010, Papaphilippou, A. 2012),

Gorbanyov, M. 2010 and Papaphilippou, A. 2012, have been modelled and aggregate supply and coefficients were estimated production function, used as a model, taking values $0.54,0.58$ and 0.42 and 046 respectively. In estimating these coefficients was used calibration method based on the ratio of capital to GDP in 1999 equal to 2.5, then using the formula for capital accumulation series data for GDP and employment, annual values was calculated TFP using production function model.

In in the publications (Casadio, P., Paradiso, A. and R. B. Bhaskara, 2011) have proceeded as follows. From economic growth in the state of the model Sollow stability (Solow, R. M.1956) $y^{*}=\left(\frac{s}{\delta+g+n}\right)^{\alpha /(1-\alpha)} A$, here $y^{*}=Y / L$ is the amount of income per capita in the state of stability, $s$ is the ratio of investment to income, $\delta$ is the depreciations rate of capital, $g$ is the rate of technical progress, $n$ is the rate of population growth and $\alpha$ is the exponential power of the capital in the Cobb-Douglas production function. This implies that the growth rate in the state of stability is as follows $\Delta \ln y^{*}=\Delta \ln A=P T F$. Then, the production function $Y_{t}=A_{t} K^{\alpha} L^{(1-\alpha)}$ is considered and the stock of knowledge in it evolves the form $A_{t}=A_{0} e^{\left(\gamma_{i} Z_{i t}+\phi_{1} S_{t}+\phi_{2} S_{t}^{2}+\varphi_{1} W_{t}\right)}$. After some transformations is obtained $\ln y_{t}=\ln A_{0}+\gamma_{i} Z_{i t} t+\phi_{1} S_{t}+\phi_{2} S_{t}^{2}+\varphi \cdot W_{t}+\alpha \ln k_{t}$ here $y=Y / L$ and $k=K / L$. So, GDP depends on the production factors accumulation and on the variables that do not relate to the production factors: $Z, S, W$. Because the stability state $\Delta \ln k \rightarrow 0$, GDP growth rate is equal to the stock of knowledge, which is shown in the publications (Liubici F., Harazasvili I., Denisiuc V., 2009). Therefore, the authors have proposed two methods for determining the growth of the GDP:

$$
\begin{aligned}
& g_{1}=\gamma_{i} Z_{i t} \\
& g_{2}=\gamma_{i} \Delta Z_{i t}+\gamma_{i} Z_{i t}+\phi_{1} \Delta S_{t}+2 \phi_{2} \Delta S+S_{t}+\varphi \cdot \Delta W_{t}
\end{aligned}
$$

In the case when $Z_{1}=T R A D E, Z_{2}=I R A T, S=H K I$ as the first variable is the share of Trade Balance in GDP, the second variable is the ratio of investment to GDP and the third variable is nothing than the human capital indices.

So, Ukrainian researchers approach from the publications (Liubici F., Harazasvili I., Denisiuc V., 2009) proposes for the TFP estimation an iterative algorithm that ensures convergence of the effectiveness indicator to the Total Factor Productivity indicator. And the approach offered in the publications (Turcan, A., 2010) provides this indicator estimation through regresional calculus.

We try to apply both approaches to the economic situation of the MR. Based on the statistical information on the main macroeconomic indicators evolution for the years 2000-2011 in current prices, GDP and capital data were recalculated per engaged in work. Then were perfected data for educational level using (Turcan, A., 2010) data for investments, net export offered by NBS were used to calculate these indicators share in GDP. Capital was calculated based on the accumulation relationship, based on the GDP value equal to 2.5 for 2000 (A. Papaphilippou, 2012), applying the formula $K_{t}=(1-\rho) K_{t-1}+\operatorname{In} v_{t}$ rate of capital depreciation receiving values 0.023 and 0.04 (A. Papaphilippou, 2012), and then to apply the of Ordinary Least Squares Method for the GDP and TFP estimations respectively. As in the publications Casadio, P, 2011 to estimate GDP were used three variables not related to the of production factors: share of net exports in GDP, share of investment in GDP and the human capital indices in the following formula: 


$$
\begin{aligned}
& \ln y_{t}=\text { Const }+\alpha \ln k_{t}+\phi_{1} \ln H K I_{t}+\phi_{2}\left(\ln H K I_{t}\right)^{2}+\gamma_{1} \ln H K I_{t} \cdot t+ \\
& +\gamma_{2} \cdot T R A D E_{t} \cdot t+\gamma_{3} E R A T_{t} \cdot t
\end{aligned}
$$

For, $\rho=0.023$ after several calculations was appealed to a more appropriate from economic point of view functional form, containing variable with increased significance

$$
\begin{aligned}
& \ln y_{t}=\text { Const }+\alpha \ln k_{t}+\phi_{2}\left(\ln H K I_{t}\right)^{2}+\gamma_{1} \ln H K I_{t} \cdot t \\
& \begin{array}{llll}
-0.6279 & 0.4385 & 0.009 & 0.9483
\end{array} \\
& \begin{array}{llll}
(3.0576) & (0.2018) & (0.0150) & (0.2505)
\end{array} \\
& \text { [-0.2054] [2.1733] [6.6389] [3.7853] } \\
& R^{2}=0.9974, F=1032
\end{aligned}
$$

in the round parentheses are standard deviations and in those squares are t-statistics.

While for $\rho=0.04$ in the same formula $R^{2}=0.9987, F=1020$

$$
\begin{array}{cccl}
\ln y_{t}=\text { Const }+\alpha \ln k_{t}+\phi_{2}\left(\ln H K I_{t}\right)^{2}+\gamma_{1} \ln H K I_{t} \cdot t \\
-1.9102 & 0.4876 & 0.009 & 0.9483 \\
(3.5731) & (0.2218) & (0.0131) & (0.2862) \\
{[-0.5346]} & {[2.1987]} & {[8.1598]} & {[3.725]}
\end{array}
$$

In parentheses are standard deviations indicated in those squares and t-statistics, $R 2=0.9974, F=1041.289$.

The TFP coefficient calculating in accordance with approach offered in [1] will be based on the indicators values: GDP in relation to production volume, education level, labour utilization, the poverty rate of the shadow economy, trade balance, so $E F_{t}=\prod_{1}^{6} k_{i}$. Using historical data for these indicators, the effectiveness index values for all years in review were calculated.

Note, that applying three approaches outlined above, averages result were obtained: 1. PTF ese examined as exponential term in production function estimated using statistical data on investment, which is equal to $0.059,2$. TFP is calculated based on indicators that are educational level, with an estimated value of $0.056,3$. PTF is assessed against the product of six socio-economic indicators, refer to the power exponential increase in the production function and equals 0.041 . Reveals that the first two values are very close, while the third value is much lower. Explanation could be that values of the indicators used in this calculation are of the lower credibility.

Table 1. Lstimated value of the TFP and Iny lognormal logarithm from GDP/L

\begin{tabular}{|c|c|c|c|c|c|c|c|c|c|c|c|c|}
\hline Yars/ $\rho$ & 2000 & 2001 & 2002 & 2003 & 2004 & 2005 & 2005 & 2007 & 2008 & 2009 & 2010 & 2011 \\
\hline 0.023 & 5.43 & 5.58 & 5.72 & 5.86 & 5.99 & 6.12 & 6.21 & 6.28 & 6.34 & 6.39 & 6.43 & 6.52 \\
\hline 0.04 & 5.02 & 5.16 & 5.30 & 5.43 & 5.56 & 5.67 & 5.75 & 5.81 & 5.87 & 5.91 & 5.94 & 6.03 \\
\hline Iny .023 & 9.26 & 9.46 & 9.64 & 9.88 & 10.09 & 10.29 & 10.47 & 10.65 & 10.80 & 10.92 & 11.02 & 11.15 \\
\hline Iny 0.04 & 9.26 & 9.46 & 9.64 & 9.88 & 10.09 & 10.29 & 10.47 & 10.65 & 10.80 & 10.92 & 11.02 & 11.15 \\
\hline
\end{tabular}

Calculation (Total Factor Productivity) PTF under the approach will be made based on the values of the six indicators above, the supplement to the rate of remittances in GDP, the rate of investment in GDP

Table 2. Total Factor Productivity

\begin{tabular}{|l|c|c|c|c|c|c|c|c|c|c|c|}
\hline Years & 2001 & 2002 & 2003 & 2004 & 2005 & 2005 & 2007 & 2008 & 2009 & 2010 & 2011 \\
\hline GDP/X & 0.473 & 0.459 & 0.459 & 0.452 & 0.455 & 0.460 & 0.447 & 0.440 & 0.4473 & 0.480 & 0.482 \\
\hline Education & 0.107 & 0.105 & 0.102 & 0.1 & 0.098 & 0.095 & 0.092 & 0.089 & 0.086 & 0.083 & 0.081 \\
\hline Labour & 0.199 & 0.198 & 0.221 & 0.184 & 0.154 & 0.167 & 0.163 & 0.186 & 0.212 & 0.246 & 0.283 \\
\hline Poverty & 0.678 & 0.546 & 0.404 & 0.29 & 0.265 & 0.302 & 0.258 & 0.264 & 0.263 & 0.219 & 0.204 \\
\hline
\end{tabular}




\begin{tabular}{|l|c|c|c|c|c|c|c|c|c|c|c|}
\hline Informal economy & 0.4 & 0.4 & 0.4 & 0.4 & 0.4 & 0.4 & 0.4 & 0.4 & 0.4 & 0.4 & 0.4 \\
\hline Trade & -0.24 & -0.25 & -0.34 & -0.30 & -0.41 & -0.47 & -0.52 & -0.53 & -0.37 & -0.39 & -0.41 \\
\hline PTF & $\mathbf{6 . 6}$ & $\mathbf{5 . 2}$ & $\mathbf{5 . 6}$ & $\mathbf{2 . 9}$ & $\mathbf{3 . 0}$ & $\mathbf{4 . 1}$ & $\mathbf{3 . 6}$ & $\mathbf{4 . 1}$ & $\mathbf{3 . 3}$ & $\mathbf{3 . 4}$ & $\mathbf{3 . 7}$ \\
\hline
\end{tabular}

Source: Created by author based on information from http://www. statistica.md

\section{Concluding remarks}

Access to existing statistics in Moldova innovation is limited. Statistical indicators should be relevant both to reflect the situation at national level and to make international comparisons as well as statistical and mathematical estimates.

Using statistical data for these indicators of effectiveness was calculated indicator values for all years under examination.

Note that the average values obtained in the result of the above three approaches:

1. TFP is considered as exponential term in the production function estimated using statistical data on investment, which is equal to 0059

2. TFP is calculated based on indicators, which is the educational level, with an estimated 0056 value

3. PTF product is assessed against six socio-economic indicators, which refers to the exponential power production function and equals 0.041 .

Reveals that the first two values are very close, while the third value is much lower. Explanation could be that the values of the indicators used in this calculation are of lower credibility.

\section{References}

Apostolos Papaphilippou, Notes on the Cobb-Douglas Production Function Model, the Growth Elasticity of Poverty, and the Calibration and Use of the Spreadsheet Model Using Moldovan Data, Chisinau, 2012.

Casadio, P., Paradiso, A. and R. B. Bhaskara, Estimates of the steady state growth rates for the Scandinavian countries: a knowledge economy approach, Munich Personal RePEc Archive, 2011, May.

Gorbanyov, M., "Factors and features of Economic Growth", in: Republic of Moldova: Selected Issues Paper, IMF Country Report No. $10 / 232,2010$.

Haque N.U., Lahiri K. and Montiel P., "An Econometric Rational-Expectations Macroeconomic Model for Developing Countries with Capital Controls"

Naval E., Geru V., Increasing the role of state investment in knowledge based economic growth. In: Materialele Conferinţei Ştiinţifice Internaţionale „Creşterea Competitivităţii şi Dezvoltarea Economiei Bazate pe Cunoaştere”,28-29 septembrie, 2007, Vol. II, Chişinău 2008.

Perchinschi Natalia, Gribincea Alexander, Iscenco Alexander, Imitation Model of the Inovation Development of a Countrz in Conditions of Internationaliyation. RevistaEconomică, Vol. 42-43, p.33-41, 2008, Sibiu, România.

Solow, R. M. A contribution to the theory of economic growth, Quarterly Journal of Economics, 1956, 70, 65-94.

Romer, P., "Endogenous technological change." Journal of Political Economy, 98(5), 1990.

Jurcan A., Chirita L. Analiza situaţiei statisticii în domeniul ştiinţei şi inovării în Republica Moldova. Revista „Intellectus” 1/2010, pag.48-54.

Turcan (Şuşu), A., Naval, E. Aplicarea aparatului matematico-statistic în scopul estimarii indicatorilor de creştere inovaţională = Aplication the Statistical and Mathematical Methods for Estimating the Indicators of The Innovation Growth. In: Economie si Sociologie. 2012, nr. 4, pp. 92-104.

Ţurcan (Şuşu) A. Problematica elaborării sistemului de indicatori statistici în domeniul ştiinţei şi inovării în Republica Moldova Revista „economie şi sociologie" (B) 1/2012, pag. 34-47.

Любич Ф.Ф., Харазишвили Ю.М., Денисюк В.А., Формирование критериев и модели оценки инновационности социальноэкономического развития. Инновации, № 9 (131),2009. стр.106-111.

Иванова И.И., Дежина И.Г., Анализ инновационной политики и оценка ее результатов Инновации, №7б 2008.

Кротов С.В., Анализ региональных иновационных процессов на базе эволюционной модели, Журнал экономической теории УрО НАН. №1,2004.

Садков В.Г., Машеговолаевич П.Н. и др. Уровень инновацион-ности общественного развития (методологические аспекты). Инновации, №9, 2002.

http://www.barrolee.com/data/newtest.jsp 